Article

\title{
The Effect of Transglutaminase to Improve the Quality of Either Traditional or Pectin-Coated Falafel (Fried Middle Eastern Food)
}

\author{
Asmaa Al-Asmar ${ }^{1,2}\left(\mathbb{D}\right.$, C. Valeria L. Giosafatto ${ }^{1}\left(\mathbb{D}\right.$, Lucia Panzella ${ }^{1(D)}$ and \\ Loredana Mariniello $1, *$ (D) \\ 1 Department of Chemical Sciences, University of Naples "Federico II", 80126 Naples, Italy; \\ asmaa.alasmar@unina.it (A.A.-A.); giosafat@unina.it (C.V.L.G.); panzella@unina.it (L.P.) \\ 2 Analysis, Poison control and Calibration Center (APCC), An-Najah National University, \\ P.O. Box 7 Nablus, Palestine \\ * Correspondence: loredana.mariniello@unina.it; Tel.: +39-81-253-9470
}

Received: 16 April 2019; Accepted: 21 May 2019; Published: 23 May 2019

\begin{abstract}
In this study, the effect of transglutaminase (TGase) (5 or $20 \mathrm{U} / \mathrm{g}$ of chickpea proteins) on falafel dough was investigated. The resulting falafel balls were either treated or not by dipping them into a pectin (PEC 1\%) coating solution. Acrylamide (ACR), oil, and water content were then evaluated. Texture profile analyses and in vitro gastric digestion experiments were also carried out. The ACR content was reduced by $10.8 \%$ and by $34.4 \%$ in the samples prepared with 5 and $20 \mathrm{U}$ TGase/g, respectively. In PEC-coated samples, the reduction of ACR was equal to 59.3\%, 65.3\%, and $84.5 \%$, in falafel balls prepared either without TGase or containing $5 \mathrm{U}$ or $20 \mathrm{U}$ of the enzyme, respectively. However, TGase treatment did not affect oil content, while the PEC coating reduced oil uptake by $23.5 \%$. No difference was observed in the texture properties between the control sample and the one dipped in PEC, while these properties changed in samples prepared with the enzyme. Finally, digestion studies, carried out under physiological conditions, demonstrated that the falafels prepared in the presence of TGase were efficiently digested in the gastric environment.
\end{abstract}

Keywords: falafel; acrylamide; transglutaminase; pectin; oil uptake

\section{Introduction}

Falafel is a traditional fast food or street food in the Middle East, also known as "ta'amiyya" in Egypt and Sudan; it is a deep fried ball made of spiced fava beans and/or chickpeas [1,2]. Nowadays, several countries, like Palestine, Jordan, Lebanon, Syria, and other Middle Eastern countries, use chickpeas to prepare this popular fast food that is eaten for both breakfast and dinner. Chickpeas have been used as a popular food in the East since 4000 BC [3]. Falafel dough is made of a mixture of soaked ground chickpeas, parsley, onions, spices and is leavened by sodium bicarbonate. The dough is shaped as balls just before deep-frying in vegetable oil until they become crusty and brown [2,4]. According to the United States Department of Agriculture (USDA) [5], homemade falafel contains $13.3 \%$ proteins, $17.8 \%$ total fat, $31.8 \%$ carbohydrate and is a rich source of different minerals like calcium, magnesium, phosphorus, potassium, sodium, and also vitamins, such as folate, vitamin $\mathrm{C}$, and vitamin $\mathrm{A}$.

The exposure of starch containing foods to temperatures above $120{ }^{\circ} \mathrm{C}$ in a low moisture environment provokes formation of acrylamide ( $\mathrm{ACR}, \mathrm{H}_{2} \mathrm{C}=\mathrm{CH}-\mathrm{CO}-\mathrm{NH}_{2}$ ), which is highly soluble in water [6,7]. According to the European Food Safety Authority (EFSA), ACR is produced in numerous baked and fried foods, including French fries, potato crisps, breads, biscuits, and coffee (roasted beans). EFSA scientists conclude that ACR is a health concern [8]. Moreover, the pathway of 
ACR formation probably involves Strecker degradation of amino acids, especially asparagine in the presence of dicarbonyl products from the Maillard reaction. Al-Dmoor et al. [4], indicated that ACR in Jordanian fried falafel (cooked for 6-8 $\mathrm{min}$ at $160-180^{\circ} \mathrm{C}$ ) is present in very high values ranging from 2700 to $4200 \mu \mathrm{g} \cdot \mathrm{kg}^{-1}$, moreover, the same study demonstrated that the excessive use of frying oil in food preparation causes significant increases $(\sim 33 \%)$ in ACR content. Very little work has been done to decrease oil absorption in fried falafel balls. The only indications come from Abu-Alruz [2], who assessed that increasing falafel ball size provokes a reduction of oil uptake together with a decrease in frying time.

Transglutaminases (TGase, EC 2.3.2.13) are a widely distributed groups of enzymes that crosslink proteins through an acyl-transfer reaction resulting in an $\varepsilon$ - $(\gamma$-glutamyl)lysine isopeptide bond. Recently, using TGase to improve the physiochemical properties of different food products, and also edible films and coatings, has increased in popularity, due to the ability of TGase to improve the crosslink network inside the food matrixes $[9,10]$. Due to the enzymatic cross-linking of milk proteins by TGase, yoghurt viscosity and yield stress were increased [11]. Moreover, many proteins were successfully found to be a substrate of TGase, such as egg proteins [12], fish proteins [13], soy proteins [14,15], bitter vetch proteins [16], and grass pea proteins [17].

Pectins (PECs) are plant cell wall structural polysaccharides composed mainly of galacturonic acid units with variations in composition, structure, and molecular weight [18]. In general, PECs are used as food additives (E440), known as thickers or stabilizers, to prepare different food products like jelly, jam, marmalades and other products, due to their gelling properties [19]. PEC is also used in pharmaceuticals and cosmetics industry due to all these properties. Moreover, PEC applications are devoted to increase, since these biopolymers have great potential for future developments [20]. Coatings are one of the most important food preservation methods that are applied to protect highly perishable foods by creating a thin layer of edible materials onto surfaces of the products. For example, Yossef. [21], found out that PEC coated strawberry fruits retained physico-chemical properties and a visual quality comparable to the ones coated by soy proteins, gluten, or starch.

Healthy food is becoming the most interesting objective for several industries and for a large portion of consumers, since many health problems are correlated to the consumption of food products. Recently, Al-Asmar et al. [22] concluded that the use of PEC as a dip coating material for French fries provokes a reduction of about $48 \%$ in ACR formation in comparison to uncoated samples. Moreover, Suyatma et al. [23] have studied the synergistic effect of blanching and PEC coating of fried banana chips, which resulted in high ACR reduction (up to 91.9\%).

The objective of this study was to evaluate the effects of both TGase and PEC-based coating solutions on the ACR formation and quality of the fried falafel. Oil and water content, texture analysis profile, and in vitro gastric digestion were investigated.

\section{Materials and Methods}

\subsection{Materials}

ACR standard $\geq 99.8 \%$, and methanol were supplied from the Sigma-Aldrich Chemical Company (St. Louis, MO, USA). Acetonitrile HPLC analytical grade, $n$-hexane, and formic acid were obtained from Carlo Erba reagents S.r.l. (Cornaredo, Milan, Italy). Oasis HLB $200 \mathrm{mg}, 6 \mathrm{~mL}$ solid phase extraction (SPE) cartridges were from Waters (Milford, MA, USA). Syringe filters (0.45 and $0.22 \mu \mathrm{m}$ PVDF) were from Alltech Associates (Deerfield, Italy). PEC of a low-methylated citrus peel (7\%) (Aglupectin USP) was purchased from Silva Extracts s.r.l. (Gorle, Bergamo, Italy), and Activa®WM Streptoverticillium TGase was supplied by Ajinomoto Co (Tokyo, Japan). All the other reagents were of analytical grade. Corn oil and chickpeas were purchased from a local super market. 


\subsection{Preparation of PEC Coating Solutions}

PEC-based solutions $(1 \% w / v)$ were prepared according to Al-Asmar et al. [22] and Esposito et al. [24], from a PEC stock solution $(2 \% w / v)$, then diluted with water, and the $\mathrm{pH}$ was adjusted from 3.2 to 7.5 with $\mathrm{NaOH} 1 \mathrm{~N}$, by means of a digital $\mathrm{pH}$ meter (Basic20, Crison, Barcellona, Spain). Finally, the solution was stirred for $30 \mathrm{~min}$ at $25^{\circ} \mathrm{C}$.

\subsection{Falafel Preparation and Dipping Process}

\subsubsection{Falafel Dough Preparation}

$100 \mathrm{~g}$ of dough were made up of a mixture of soaked chickpeas $(76 \mathrm{~g})$, onion (10 g), parsley $(3 \mathrm{~g})$, falafel spices $(0.3 \mathrm{~g})$, salt $(1.5 \mathrm{~g})$, and sodium bicarbonate $(0.2 \mathrm{~g})$. The mixture was blended for 2 min with water. A special scoop (Inner diameter $4 \mathrm{~cm}$, depth $1 \mathrm{~cm}$ ) was used for preparing the falafel balls, each one with a diameter of $4 \mathrm{~cm}$ and weighing around $17 \mathrm{~g}$. Then the balls were fried as described below.

\subsubsection{Falafel Dough Treated with TGase}

After prepared the falafel dough as described above, TGase ( 5 and $20 \mathrm{U} / \mathrm{g}$ protein) was added to the dough and incubated at $37^{\circ} \mathrm{C}$ for $2 \mathrm{~h}$. The falafel balls were then formed and fried. The control falafel samples were obtained without TGase but treated under the same experimental conditions.

\subsubsection{PEC Dipping}

The falafel balls, either treated or not with TGase, were frozen at $-20{ }^{\circ} \mathrm{C}$ for $2 \mathrm{~h}$, then dipped in $1 \%$ PEC, whereas the control was dipped in water. Each kind of dipped ball was frozen again for $30 \mathrm{~min}$ and then fried. In Table 1 the experimental design is described.

Table 1. Experimental design followed for performing all the analyses.

\begin{tabular}{cccc}
\hline Falafel Type & TGase (U/g Protein) & Incubation $\mathbf{2} \mathbf{h}$ at $\mathbf{3 7}{ }^{\circ} \mathbf{C}$ & Dipping Solution \\
\hline Traditional falafel & - & - & - \\
Incubated without TGase & 0 & $\sqrt{ }$ & - \\
Incubated with TGase (5 U/g) & 5 & $\sqrt{ }$ & - \\
Incubated with TGase (20 U/g) & 20 & - & Water \\
Dipped & - & $\sqrt{ }$ & $1 \%$ PEC \\
Incubated without TGase & 0 & $\sqrt{ }$ & $1 \%$ PEC \\
Incubated with TGase (5 U/g) & 5 & $\sqrt{ }$ & $1 \%$ PEC \\
Incubated with TGase (20 U/g) & 20 & & \\
\hline
\end{tabular}

\subsection{Frying Process}

Falafel balls were fried at $180 \pm 5{ }^{\circ} \mathrm{C}$ for $5 \mathrm{~min}$, by using $2 \mathrm{~L}$ of corn oil, using a deep-fryer apparatus (Girmi, Viterbo, Italy) [22,25]. The oil was replaced with fresh oil for each group. Each fried group was flipping from side to side every $2 \mathrm{~min}$. After frying, each sample was allowed to drain for $2 \mathrm{~min}$ to remove the excess oil [22].

\subsection{Sodium Dodecyl Sulphate Polyacrylamide Gel Electrophoresis (SDS-PAGE)}

For the SDS-PAGE of falafel balls, an aliquot of $250 \mu \mathrm{L}$ of sample buffer $(15 \mathrm{mM}$ of Tris- $\mathrm{HCl}, \mathrm{pH}$ 6.8, containing $0.5 \%(w / v)$ of SDS, $2.5 \%(v / v)$ of glycerol, $200 \mathrm{mM}$ of $\beta$-mercaptoethanol, and $0.003 \%(w / v)$ of bromophenol blue), was added to $25 \mathrm{mg}$ of falafel dough and/or whole fried falafel (either untreated or treated with TGase) after grinding. Each aliquot was analyzed by $12 \%$ SDS-PAGE. The samples were heated at $100^{\circ} \mathrm{C}$ for $5 \mathrm{~min}$, and then centrifuged for $10 \mathrm{~min}$ at $13000 \times \mathrm{g}$. Ten $\mu \mathrm{L}$ of each supernatant was analyzed by SDS-PAGE (12\%). SDS-PAGE was performed as described by Laemmli [26], at a constant 
voltage ( $80 \mathrm{~V}$ for 2-3 h), and the proteins were stained with Coomassie Brilliant Blue R250 (Bio-Rad, Segrate, Milan, Italy). Bio-Rad Precision Protein Standards were used as molecular weight markers.

\subsection{In Vitro Gastric Digestion}

Fried falafel balls, either treated or not by TGase (20 U/g protein), were subjected to in vitro digestion (IVD) by using an adult model $[12,27,28]$, under gastric physiological conditions. For our analyses, $100 \mathrm{mg}$ of each sample were incubated with $4 \mathrm{~mL}$ of Simulated Salivary Fluid (SSF, $150 \mathrm{mM}$ of $\mathrm{NaCl}, 3 \mathrm{mM}$ of urea, $\mathrm{pH}$ 6.9) containing $75 \mathrm{U}$ of amylase enzyme/g protein for $5 \mathrm{~min}$ at $37^{\circ} \mathrm{C}$ and $170 \mathrm{rpm}$. The amylase activity was blocked by adjusting the $\mathrm{pH}$ at 2.5 . Afterwards, the samples were subjected to gastric digestion as described by Giosafatto et al. [12] with some modifications. Briefly, $100 \mu \mathrm{L}$ of Simulated Gastric Fluid (SGF, $0.15 \mathrm{M}$ of NaCl, pH 2.5) were placed in $1.5 \mathrm{~mL}$ microcentrifuge tubes and added to $100 \mu \mathrm{L}$ of oral phase and then incubated at $37^{\circ} \mathrm{C}$. Thereafter, $50 \mu \mathrm{L}$ of pepsin $(0.1 \mathrm{mg} / \mathrm{mL}$ dissolved in SGF) were added to start the digestion reaction. At intervals of $1,2,5,10,20$, 40 , and $60 \mathrm{~min}, 40 \mu \mathrm{L}$ of the $0.5 \mathrm{M}$ of ammonium bicarbonate $\left(\mathrm{NH}_{4} \mathrm{HCO}_{3}\right)$ were added to each vial to stop the pepsin reaction. The control was set up by incubating the sample for $60 \mathrm{~min}$ without the protease. The samples were then analyzed using the SDS-PAGE (12\%) procedure described above.

\subsection{ACR Standard Preparation}

The standard stock solution $(1.0 \mathrm{mg} / \mathrm{mL})$ was prepared as described by Al-Asmar et al. [22]. Then, it was diluted at different concentrations $(50,100,250,500,1000,2000,3000,4000,5000$, and 10,000 $\mu \mathrm{g} / \mathrm{L}$ ), respectively. All series of standard solutions were stored in glass dark bottles (light-resistant) at $4{ }^{\circ} \mathrm{C}$ until used.

\subsection{Extraction of ACR from the Falafel Balls}

ACR extraction from fried falafel balls was carried out according to Al-Asmar et al. [22], with some modifications. About $160 \mathrm{~g}$ of fried falafel balls, after cooling, were immersed in hexane for $30 \mathrm{~min}$ to remove the oil from their surfaces [29]. The falafel balls were then ground by using a rotary mill (Grindomix GM200, Retsch GmbH, Haan, Germany) at a speed of $1300 \mathrm{rpm}$ for $1 \mathrm{~min}$. Each sample was allowed to dry by freeze-drying before being subjected to ACR extraction following the protocols reported by Wang et al. [30] and Krishna et al. [31]. Two different falcon tubes were set up for each sample, one for detecting ACR formed in the sample itself, and the second one to carry out the recovery test. In both tubes, $1 \mathrm{~g}$ of the grinded sample was placed inside, but only in the second tube $100 \mu \mathrm{g} / \mathrm{L}$ of ACR standard were added. Fifty $\mu \mathrm{L}$ of Carrez reagent potassium salt and $50 \mu \mathrm{L}$ of Carrez reagent zinc salts were added to each sample. In each tube, $10 \mathrm{~mL}$ of HPLC water were added. The samples were extracted in an incubated shaker for $30 \mathrm{~min}$ at $25^{\circ} \mathrm{C}$ and $170 \mathrm{rpm}$, followed by centrifugation at $8000 \mathrm{rpm}$ for $10 \mathrm{~min}$ at $4{ }^{\circ} \mathrm{C}$. The supernatant was filtered through a $0.45 \mu \mathrm{m}$ syringe filter for Oasis HLB SPE cartridges clean-up. The SPE cartridge was conditioned with $2 \mathrm{~mL}$ of methanol followed by $2 \mathrm{~mL}$ of HPLC water before loading $3 \mathrm{~mL}$ of filtered supernatant; the first $0.5 \mathrm{~mL}$ were discarded, and the remaining elute were collected $(\approx 1.5 \mathrm{~mL})$. The different extracts were all kept in dark glass vials at $4{ }^{\circ} \mathrm{C}$ before analysis. The clean sample extracts were further filtered through $0.2 \mu \mathrm{m}$ nylon syringe filters and analyzed by TOF LC-MS. Each analysis was performed in triplicate.

\subsection{LC-MS Analysis for ACR Content of Fried Falafel}

The determination of ACR concentration was performed using the Agilent 6230 TOF-LC/MS (Agilent Technologies, Santa Clara, CA, USA) coupled to a series HPLC system, a vacuum degasser, binary pumps, and a temperature-controlled column oven at $30^{\circ} \mathrm{C}$. The following MS parameters were used: positive ion mode, nebulizer pressure $35 \mathrm{psi}$, drying gas $\left(\mathrm{N}_{2}\right) 5 \mathrm{~L} / \mathrm{min}$ and $325^{\circ} \mathrm{C}$, capillary voltage $3500 \mathrm{~V}$, and fragmentor $175 \mathrm{~V}$.

The column used was a Synergi ${ }^{\mathrm{TM}} 4 \mu \mathrm{m}$ Hydro-RP $80 \AA$ A HPLC Column at $250 \mathrm{~mm} \times 3 \mathrm{~mm}$ [22,32] (from Phenomenex, Torrance, CA, USA). The operating conditions were as follows: the mobile phase 
was a gradient elution: mixture water/acetonitrile $(97 / 3, v / v)$ containing $0.10 \%(v / v)$ formic acid Solvent A and Solvent B was acetonitrile containing $0.10 \%(v / v)$ formic acid. The program elution was applied as follows: $100 \% \mathrm{~A}(0 \% \mathrm{~B})$ for $8 \mathrm{~min}$, increased to $80 \% \mathrm{~B}(20 \% \mathrm{~A})$ from 8 to $15 \mathrm{~min}$, and kept at $80 \% \mathrm{~B}$ (20\% A) for $10 \mathrm{~min}$, increased to $100 \% \mathrm{~A}(0 \% \mathrm{~B})$ from 25 to $30 \mathrm{~min}$ and kept at $100 \% \mathrm{~A}$ for $5 \mathrm{~min}$, at a flow rate of $0.4 \mathrm{~mL} / \mathrm{min}$. The injection volume was $20 \mu \mathrm{L}$. The total chromatographic runtime was $35 \mathrm{~min}$ for each sample; ACR elutes at a retention time of $3 \mathrm{~min}$, and then the peak identification was based on the Extracted Ion Chromatogram (EIC); by selecting the ion at $m / z 72$, calibration curves were obtained by plotting the peak area of ACR versus concentration of ACR (range of concentration: $0.05-10 \mathrm{mg} / \mathrm{L}$ ). The equation was obtained by applying the linear regression of $y=102.21 x-10.706$, with $R^{2}$ equal to 0.9991 ; this equation was used to calculate the amount of ACR in all analyzed samples.

\subsection{Oil Content}

Each fried falafel ball was ground into pieces ( $3-5 \mathrm{~g})$. The oil content was measured gravimetrically in triplicate by using the Soxhlet method [33] and reported as a percentage on dry matter weight.

\subsection{Water Content Analysis}

The water content of each fried falafel ball sample was measured gravimetrically in triplicate, according to Association of Official Analytical Chemists (AOAC) [34].

\subsection{Texture Profile Analysis (TPA)}

Texture profile analysis of the falafel balls for each sample was carried out as described by Rossi Marquez et al. [25], with some modifications. In particular, each falafel ball sample was analyzed using an Instron universal testing instrument model no. 5543A (Instron Engineering Corp., Norwood, MA, USA) equipped with a $2 \mathrm{kN}$ load cell in compression mode with a cylindrical probe ( $55 \mathrm{~mm}$ in diameter). The instrumental TPA described by Bourne [35] was used. The test was configured so that the three TPA parameters, hardness, chewiness, and gumminess, were calculated at the time of the test by determining the load and displacement at predetermined points on the TPA curve. Pre- and post-test speeds were $2.0 \mathrm{~mm} / \mathrm{s}$, while the test speed was $1.0 \mathrm{~mm} / \mathrm{s}$. Samples, prepared as described above, were centered and compressed to $30 \%$ deformation. Hardness $(\mathrm{N})$ was derived from the positive peak obtained at the first compression of the product or a maximum exhibited compression force. Chewiness ( $\mathrm{N} \cdot \mathrm{mm}$ ) was the mathematical product by the software Bluehill (Version 2.21) from the hardness, cohesiveness, and springiness [36]. Gumminess (N) was calculated by the software Bluehill automatically by multiply the hardness with the cohesiveness, which is a ratio of the positive force areas under the first and second compressions. All the TPA analyses were carried out with at least eight balls per treatment.

\subsection{Statistical Analysis}

All the experiments were performed three times, and the data were analyzed by using the JMP version 10.0 software (SAS Institute, Cary, NC, USA). Statistical differences were considered to be significant at $(p<0.05)$ using the 2-way ANOVA test.

\section{Results and Discussion}

\subsection{Modification of the Protein Component of Falafel Balls by Means of TGase}

Following the addition of different concentrations of TGase (0, 5, and $20 \mathrm{U}$ TGase/g chickpea protein) to the falafel dough and incubation for $2 \mathrm{~h}$ at $37^{\circ} \mathrm{C}$, the samples (both the dough and the fried falafel) were analyzed by SDS-PAGE (12\%). Figure 1 demonstrated that TGase ( 5 and $20 \mathrm{U} / g$ protein) was able, under these experimental conditions, to modify chickpea proteins. The results indicated that chickpea proteins are an effective substrate of TGase. In fact, the disappearance of proteins indicates the presence of endo-glutamine and endo-lysine reactive residues. Moreover, by increasing 
the concentration of the TGase (20 U/g protein), there was a concomitant increase of higher molecular mass polymers (Figure 1, Panels A and B).

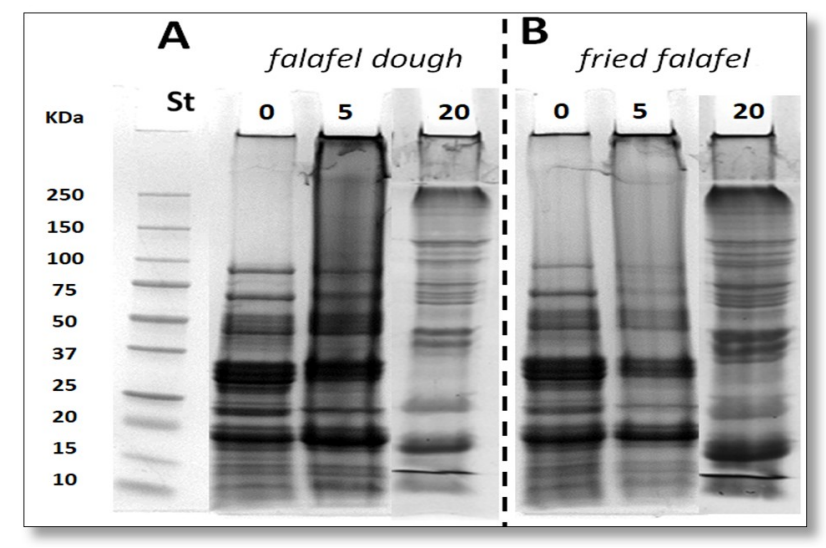

Figure 1. Panel A-SDS-PAGE of falafel dough without TGase (Lane 1), treated with $5 \mathrm{U} / \mathrm{g}$ of TGase (Lane 2) and treated with $20 \mathrm{U} / \mathrm{g}$ of TGase (Lane 3). Panel B-SDS-PAGE of fried falafel without TGase (Lane 1), treated with $5 \mathrm{U} / \mathrm{g}$ of TGase (Lane 2) and treated with $20 \mathrm{U} / \mathrm{g}$ of TGase (Lane 3). St, Molecular weight standards, Bio-Rad. Panel A: falafel dough; Panel B: fried falafel.

\subsection{Effect of TGase and/or 1\% PEC Coating Solution on the ACR Content of Falafel Balls}

According to an EFSA report, ACR is a health concern. It is formed during frying, baking or roasting starchy rich food and also in food containing a high protein concentration and sulfhydryl groups $[37,38]$. Traditional fried falafel balls were analyzed for their ACR content, which was found to be equal to $7229 \mu \mathrm{g} / \mathrm{kg}$. The falafel prepared by adding 5 or $20 \mathrm{U}$ TGase $/ \mathrm{g}$ protein, showed a reduction of ACR concentration equal to $10.8 \%$ and $34.4 \%$, respectively (Figure 2, Panel A). This reduction could be explained in two different ways: (i) the ability of TGase to crosslink the lysine and glutamine provided a network that could retain free amino acids that were involved in the ACR formation; (ii) the water content of the falafel balls prepared in the presence of TGase was higher compared to the water content of falafel prepared in the absence of the enzyme (Figure 3). In fact, Al-Asmar et al. [22] have demonstrated that, in French fries, higher moisture content was effective in lowering ACR content. 


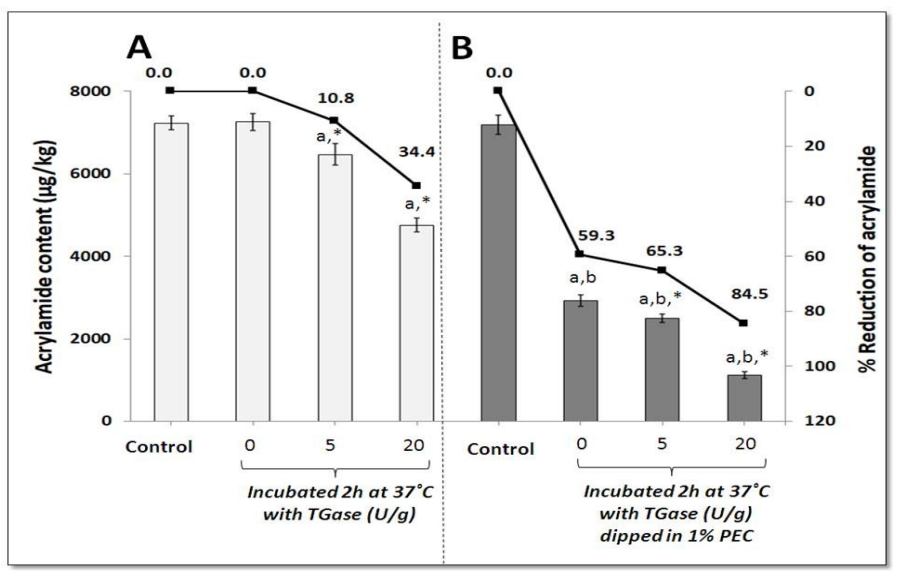

Figure 2. Effect of different concentrations of TGase on the acrylamide (ACR) content of fried falafel prepared without dipping (Panel A) or with dipping into 1\% PEC-based coating solution (Panel B). The ACR content was determinated on fat-free dry matters and reported as percentage of the ACR reduction of fried falafel balls. The columns significantly different from those obtained by analyzing the control are indicated by "a", the columns indicated by " $b$ " were significantly different from those obtained without dipping, whereas the columns indicated by "*" were significantly different from those prepared with different TGase concentrations (2-way ANOVA, $p<0.05$ ). The control of Panel A represents ACR content in traditional fried falafel. The control of Panel B represents ACR content in fried falafel dipped in water.

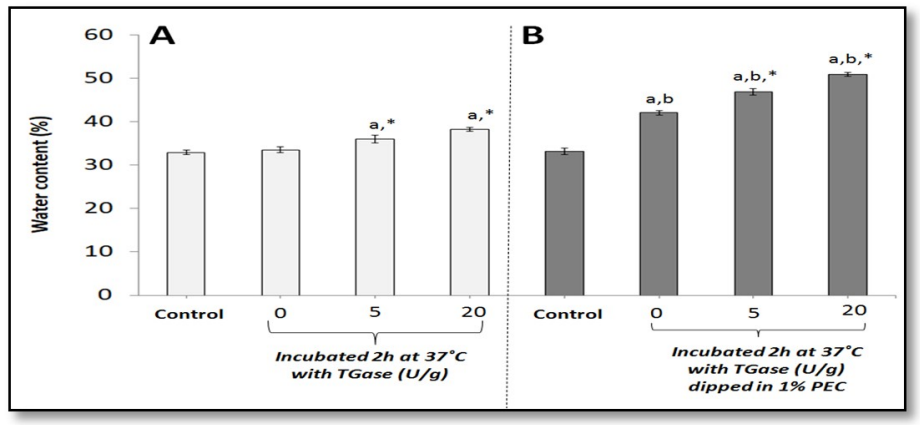

Figure 3. Effect of different concentrations of TGase on the water content of fried falafel balls prepared without dipping (Panel A) or with dipping into 1\% PEC coating solution (Panel B). The columns significantly different from those obtained by analyzing the untreated are indicated by " $a$ ", the columns indicated by " $b$ " were significantly different from those obtained without dipping, whereas the columns indicated by "**" were significantly different from those prepared with different TGase concentrations (2-way ANOVA, $p<0.05$ ). The control of Panel A represents the water content in traditional fried falafel. The control of Panel B represents water content in fried falafel dipped in water.

To study the effect of coating, the ACR content was also determined in the falafel dipped in both water or 1\% PEC-based solutions. The results, shown in Figure 2, Panel B, indicate that the ACR content was $40.7 \%$, in comparison to the ACR content of falafel dipped in water or not dipped. As shown in both Panels A and B of Figure 2, falafel balls prepared by means of TGase followed by dipping into 1\% PEC-based solution showed a significant reduction in ACR content in comparison to the uncoated falafel. The lowest amount of ACR $(1118 \mu \mathrm{g} / \mathrm{kg})$ was exhibited by falafel balls prepared by $20 \mathrm{U} / \mathrm{g}$ TGase and coated with 1\% PEC-based solutions, where the percentage of the ACR reduction was equal to $84.5 \%$. In addition, the recovery test was performed to assess the extraction efficiency for 
each sample; to this aim, the ACR content before and after the addition of $100 \mu \mathrm{g} / \mathrm{L}$ of the ACR standard was determined. Percentage recovery was determined according to the following formula [22]:

$$
\operatorname{Recovery}(\%)=\frac{\text { ACR }(\text { detected after standard addition })-\text { ACR }(\text { sample })}{\text { ACR }(\text { standard added })} \times 100
$$

The results of recovery studies are shown in Table 2. The recovery values were in the range of $89 \%-102 \%$, that are statistically in line with experimental deviations.

Table 2. Recovery test for ACR in all falafel types (in each sample $100 \mu \mathrm{g} / \mathrm{L}$ of ACR standard were added).

\begin{tabular}{|c|c|c|}
\hline Falafel Type & $\begin{array}{l}\text { ACR Content in Spiked Sample } \\
(\mu \mathrm{g} / \mathrm{Kg})\end{array}$ & Recovery (\%) \\
\hline Traditional falafel & $7329 \pm 188$ & 100 \\
\hline Incubated $2 \mathrm{~h}$ at $37^{\circ} \mathrm{C}$ without TGase & $7349 \pm 140$ & 94.2 \\
\hline Incubated $2 \mathrm{~h}$ at $37^{\circ} \mathrm{C}$ with TGase $5 \mathrm{U} / \mathrm{g}$ & $6560 \pm 147^{a, *}$ & 92.6 \\
\hline Incubated $2 \mathrm{~h}$ at $37^{\circ} \mathrm{C}$ with TGase $20 \mathrm{U} / \mathrm{g}$ & $4852 \pm 217^{a, *}$ & 96.8 \\
\hline Dipped in water & $7294 \pm 348$ & 102 \\
\hline $\begin{array}{c}\text { Incubated } 2 \mathrm{~h} \text { at } 37^{\circ} \mathrm{C} \text { without TGase and dipped } \\
\text { in } 1 \% \text { PEC }\end{array}$ & $3017 \pm 115^{a, b}$ & 90.7 \\
\hline $\begin{array}{c}\text { Incubated } 2 \mathrm{~h} \text { at } 37^{\circ} \mathrm{C} \text { with TGase }(5 \mathrm{U} / \mathrm{g}) \text { and } \\
\text { dipped in } 1 \% \text { PEC }\end{array}$ & $2583 \pm 65^{\mathrm{a}, \mathrm{b}, *}$ & 89.3 \\
\hline $\begin{array}{c}\text { Incubated } 2 \mathrm{~h} \text { at } 37^{\circ} \mathrm{C} \text { with TGase }(20 \mathrm{U} / \mathrm{g}) \text { and } \\
\text { dipped in } 1 \% \text { PEC }\end{array}$ & $1219 \pm 83^{a, b, *}$ & 101 \\
\hline
\end{tabular}

The value significantly different from those obtained by analyzing the control are indicated by "a", the value indicated by " $\mathrm{b}$ " were significantly different from those obtained without dipping, whereas the value indicated by "** were significantly different from those prepared with different TGase concentrations (2-way ANOVA, $p<0.05$ ).

\subsection{Effect of TGase and/or 1\% PEC Coatings on Water and Oil Content of Falafel Balls}

Analyzing the water content of the fried falafel indicated that the falafel prepared in the presence of TGase (5 or $20 \mathrm{U} / \mathrm{g}$ protein) contains more water in comparison to the falafel prepared without TGase or to the control (Figure 3, Panel A). Moreover, dipping the falafel into 1\% PEC-based solution increased the water content significantly compared to the control (Figure 3, Panel B).

Treating falafel with TGase and PEC-based solution increased the water content significantly compared to both controls. The TGase concentration (20 U/g protein) together with dipping into a $1 \%$ PEC-based solution retained the highest water value. The obtained results could be explained by the TGase-mediated crosslinking that is responsible for water evaporation reduction during frying [22,25].

The oil content of the falafel balls is the main problem of such fast food products that contain about $25 \%$ oil, based on the dry weight. The oil is responsible for several health problems such as cardiovascular disease and becoming overweight or obese [39]. The treatment of the falafels with ( 5 or $20 \mathrm{U} / \mathrm{g}$ protein) TGase does not show any reduction on the oil content (Figure 4, Panel A). However, the presence of the PEC-based solution significantly reduces the oil content to about $23 \%$. Many authors $[25,40,41]$ have reported that PEC leads to a lower oil uptake. For example, in the previous paper, Al-Asmar et al. [22] have demonstrated that PEC-based coating reduces oil uptake in French fries. To our knowledge, few studies have been devoted to decrease oil absorption in fried falafel balls. Pinthus et al. [42] and Mansour [43], have investigated the influence of added powdered cellulose and methyl cellulose fibers or hydrocolloids, and have demonstrated their ability to reduce oil uptake during falafel ball deep frying. 


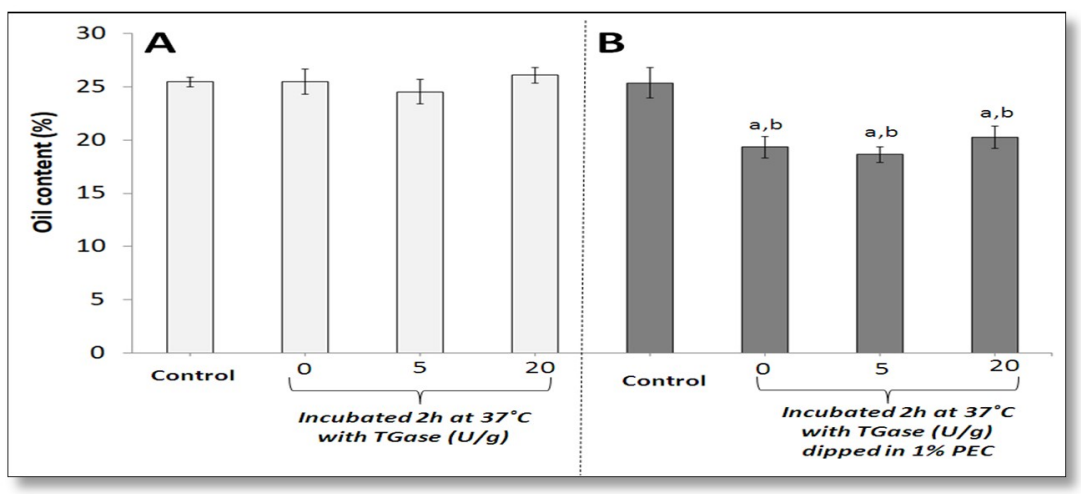

Figure 4. Effects of different concentrations of TGase without dipping (Panel A) or with dipping into a $1 \%$ PEC coating solution (Panel B), in oil content prepared based on the dry matters of the fried falafel balls. The columns significantly different from those obtained by analyzing the untreated ones are indicated by " $a$ ", whereas the columns indicated by " $b$ " were significantly different from those obtained without dipping (2-way ANOVA, $p<0.05$ ). The control of Panel A represents the oil content traditional fried falafel. The control of Panel B represents the oil content in fried falafel dipped in water.

The statistical analysis using 2-way ANOVA test indicated that both factors alone or together (dipping and TGase) significantly $(p<0.05)$ increased the water content of the falafel balls. On the other hand, dipping the falafel balls into a 1\% PEC solution significantly reduced $(p<0.05)$ the oil content, while the TGase treatment, following or without the dipping process, did not significantly influence the oil content of falafel balls.

\subsection{Effect of TGase and/or 1\% PEC Coatings on Texture Profile Analysis (TPA)}

To verify whether or not enzyme treatment and coating could influence the quality of the falafel balls, texture profile analysis (TPA) was performed. Thus, the falafel hardness, chewiness, and gumminess were assessed. As shown in Table 3, falafel balls prepared with TGase showed an increase of all three parameters. Further, TGase-treated falafel balls coated with 1\% PEC-based solution showed significantly higher hardness, chewiness, and gumminess values compared to the sample incubated in the absence of the enzyme and dipped into the PEC-based solution. As matter of fact, the statistical analysis results, obtained by using a 2-way ANOVA test, indicated that the individual factors, or together (dipping and TGase), significantly increased $(p<0.05)$ the hardness, chewiness, and gumminess of falafel balls. 
Table 3. Texture Profile Analysis (TPA) of falafel balls prepared in the presence or absence of different concentrations of TGase dipped or not into a 1\% PEC solution prepared at $\mathrm{pH} 7.5$.

\begin{tabular}{cccc}
\hline Falafel Type & Hardness $\mathbf{( N )}$ & $\begin{array}{c}\text { Chewiness } \\
\mathbf{( N \cdot m m )}\end{array}$ & Gumminess (N) \\
\hline $\begin{array}{c}\text { Traditional falafel } \\
\text { Incubated } 2 \mathrm{~h} \text { at } 37^{\circ} \mathrm{C} \text { without }\end{array}$ & $56.41 \pm 5.50$ & $184.28 \pm 3.10$ & $23.20 \pm 1.20$ \\
TGase & $52.22 \pm 5.30$ & $180.97 \pm 2.80$ & $22.15 \pm 1.20$ \\
$\begin{array}{c}\text { Incubated } 2 \mathrm{~h} \text { at } 37^{\circ} \mathrm{C} \text { with TGase } \\
5 \mathrm{U} / \mathrm{g}\end{array}$ & $70.88 \pm 3.25^{\mathrm{a}, *}$ & $238.44 \pm 2.70^{\mathrm{a}, *}$ & $\begin{array}{c}\text { Incubated } 2 \mathrm{~h} \text { at } 37^{\circ} \mathrm{C} \\
\text { with TGase } 5 \mathrm{U} / \mathrm{g}\end{array}$ \\
$\begin{array}{c}\text { Incubated } 2 \mathrm{~h} \text { at } 37^{\circ} \mathrm{C} \text { with TGase } \\
20 \mathrm{U} / \mathrm{g}\end{array}$ & $96.57 \pm 4.80^{\mathrm{a}, *}$ & $280.25 \pm 15.10^{\mathrm{a}, *}$ & $49.64 \pm 3.80^{\mathrm{a}, *}$ \\
$\begin{array}{c}\text { Dipped in water } \\
\text { Incubated } 2 \mathrm{~h} \text { at } 37^{\circ} \mathrm{C} \text { without } \\
\text { TGase and dipped in } 1 \% \text { PEC }\end{array}$ & $52.18 \pm 3.40$ & $178.13 \pm 4.10$ & $21.42 \pm 3.01$ \\
$\begin{array}{c}\text { Incubated } 2 \mathrm{~h} \text { at } 37^{\circ} \mathrm{C} \text { with TGase } \\
\text { (5 U/g) and dipped in } 1 \% \text { PEC }\end{array}$ & $114.31 \pm 8.20^{\mathrm{a}, \mathrm{b}, *}$ & $453.18 \pm 11.30 \mathrm{a}, \mathrm{b}, *$ & $67.60 \pm 4.50^{\mathrm{a}, \mathrm{b}, *}$ \\
$\begin{array}{c}\text { Incubated } 2 \mathrm{~h} \text { at } 37^{\circ} \mathrm{C} \text { with TGase } \\
(20 \mathrm{U} / \mathrm{g}) \text { and dipped in } 1 \% \text { PEC }\end{array}$ & $136.07 \pm 12.28^{\mathrm{a}, \mathrm{b}, *}$ & $518.50 \pm 18.05^{\mathrm{a}, \mathrm{b}, *}$ & $78.24 \pm 2.01^{\mathrm{a}, \mathrm{b}, *}$ \\
\hline
\end{tabular}

The results were significantly different from those obtained by analyzing the untreated are indicated by "a", whereas the results indicated by " $\mathrm{b}$ " were significantly different from those obtained without dipping. The value indicated by “*” were significantly different from those prepared with different TGase concentrations ( 2 -way ANOVA, $p<0.05$ ).

\subsection{Effect of TGase on the Digestibility of Falafel Balls}

To test the effect of enzyme-treatment on digestibility of falafel, an IVD model was used. The experiments, carried out by using a protocol set up by the INFOGEST Cost Action [44], were performed on falafel balls prepared both in the presence and absence of $20 \mathrm{U}$ TGase/g. At the end of the simulated gastric digestion, samples were analyzed by SDS-PAGE. As it is possible to see in Figure 5, the sample " $\mathrm{C}$ ", incubated in the absence or presence of TGase (Figure 5, Lane " $\mathrm{C}$ ", of both Panels A,B), contains proteins fully precipitated. Such samples were treated with only SGF without pepsin. This result is likely due to the gelation and aggregation of the food sample during the heat treatment [45]. On the other hand, as expected, when samples were treated with SGF containing pepsin, the protein component present in falafel was gradually digested. TGase slightly decreased the protein digestibility rate of the falafel balls, even though, at the end of digestion in both systems, they were completely hydrolyzed by the gastric enzyme pepsin (Figure 5). These results were also supported by the densitometry analysis (Figure 6) of the protein bands having a molecular mass between 35 and $25 \mathrm{kDa}$, (Figure 5, Panel A, samples prepared without TGase), and the high molecular mass polymers of $250 \mathrm{kDa}$ (Figure 5, Panel B, falafel balls prepared by the means of TGase). As shown in Figure 6, the digestion rate is slower in the food incubated with the TGase enzyme, even though at the end of the digestion, the proteins analyzed were fully digested by pepsin in both untreated and TGase treated falafel. 


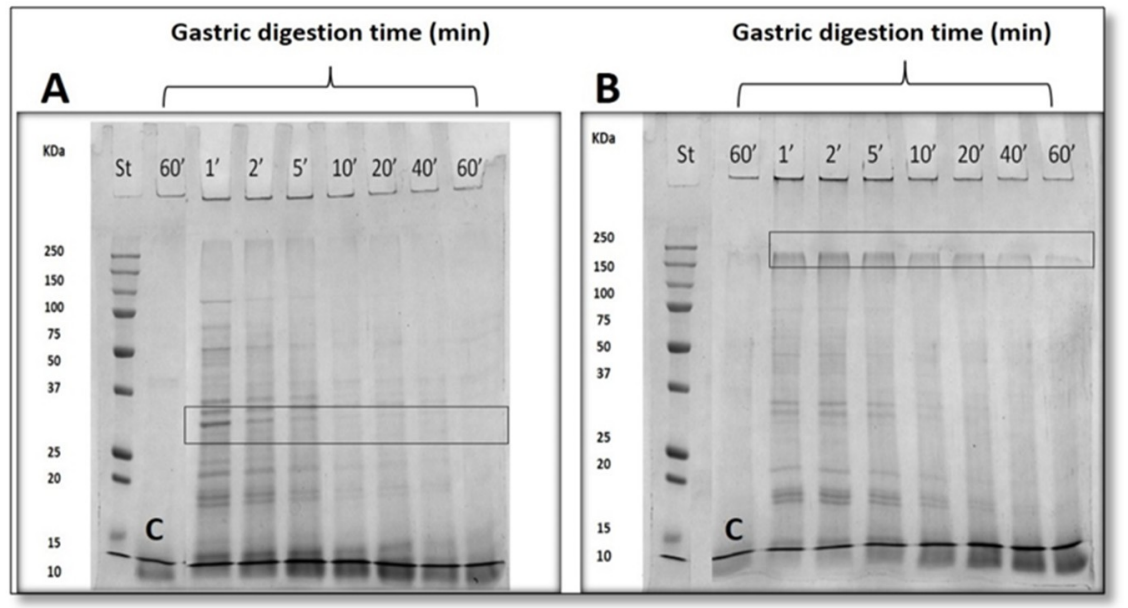

Figure 5. SDS-PAGE profile of falafel subjected to in vitro digestion (IVD) experiments. Panel A: traditional falafel prepared in the absence of TGase. Panel B: falafel prepared in the presence of TGase $(20 \mathrm{U} / \mathrm{g})$. The bands in the frame are those subjected to densitometry analysis. $\mathrm{C}$ is control sample incubated with simulated gastric solution not containing pepsin. St, Molecular weight standards, Bio-Rad.

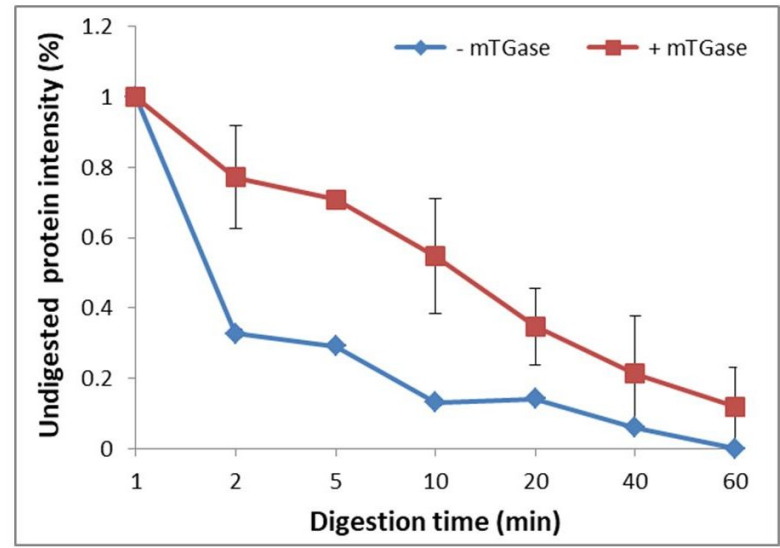

Figure 6. Densitometry analysis of the SDS-PAGE bands obtained after IVD shown in Figure 5. Both falafel types, traditional and (20 U/g) TGase-containing samples, were subjected to densitometry analysis.

\section{Conclusions}

In this paper, for the first time, falafel balls, a typical Middle Eastern food, were produced by using TGase enzyme in their dough. In addition, after their preparation, the balls were treated by dipping them in a PEC-based coating. The use of the enzyme provoked the reduction of the ACR in falafel balls, which was even more evident when TGase-prepared balls were coated by PEC, which was able to decrease the ACR concentration also present in the falafel prepared without TGase. However, TGase also had an effect on the texture profile parameters. On the other hand, the PEC coating protection reduced the oil content of this food product, either treated or not, by means of TGase. Moreover, protein gastric digestion, carried out under physiological conditions, showed that enzymatic treatment slightly decreased the digestion rate, although the proteins were fully digested at the end of the experiment in both unprocessed and TGase-processed systems.

Author Contributions: Conceptualization, A.A.-A. and L.M.; Methodology, A.A.-A. and L.P.; Software, A.A.-A. and L.P.; Validation, A.A.-A. and L.M.; Formal Analysis, C.V.L.G. and L.M.; Investigation, A.A.-A. and L.P.; Resources, L.M.; Data Curation, A.A.-A.; Writing-Original Draft Preparation, A.A.-A. and L.M.; Writing-Review and Editing, C.V.L.G. and L.M.; Visualization, A.A.-A. and L.M.; Supervision, L.M.; Project Administration, A.A.-A. and L.M.; Funding Acquisition, L.M. 
Funding: This research received no external funding.

Acknowledgments: The authors would like to acknowledge Maria Fenderico for technical support, Prospero Di Pierro and Mohammed Sabbah for advising on TPA.

Conflicts of Interest: The authors declare no conflict of interest.

\section{References}

1. Abdullah, T. Reduction of oil uptake in deep fat fried falafel. J. Nutr. Health Food Eng. 2015, 2, $114-117$. [CrossRef]

2. Abu-Alruz, K. Effect of frying time and falafel balls size on fat uptake during deep fatfrying. Am.-Eur. J. Agric. Environ. Sci. 2015, 15, 1648-1654.

3. Kantor, J. A history of the mideast in the humble chickpea. The New York Times, 10 July 2002.

4. Al-Dmoor, H.M.; Humeid, M.A.; Alawi, M.A. Investigation of acrylamide levels in selected fried and baked foods in Jordan. J. Food Agric. Environ. 2004, 2, 157-165.

5. United States Department of Agriculture. Basic Report: 16138, Falafel, Home-Prepared. Available online: https://ndb.nal.usda.gov/ndb/foods/show?ndbno=16138\&fg=\&man=\&lfacet=\&format=Abridged\& count $=\& \max =25 \&$ offset $=5675 \&$ sort $=c \& q l o o k u p=\& r p t f r m=n 1 \&$ nutrient $1=415 \&$ nutrient $2=\&$ nutrient $3=$ \&subset $=0$ \&totCount $=7669 \&$ measureby $=\mathrm{m}$ (accessed on 20 May 2019).

6. Tareke, E.; Rydberg, P.; Karlsson, P.; Eriksson, S.; Törnqvist, M. Analysis of acrylamide, a carcinogen formed in heated foodstuffs. J. Agric. Food Chem. 2002, 50, 4998-5006. [CrossRef] [PubMed]

7. Mottram, D.S.; Wedzicha, B.L.; Dodson, A.T. Food chemistry: Acrylamide is formed in the Maillard reaction. Nature 2002, 419, 448-449. [CrossRef]

8. EFSA Panel on Contaminants in the Food Chain (CONTAM). Scientific opinion on acrylamide in food. EFSA J. 2015, 13, 4104. [CrossRef]

9. Sabbah, M.; Giosafatto, C.V.L.; Esposito, M.; Di Pierro, P.; Mariniello, L.; Porta, R. Transglutaminase cross-linked edible films and coatings for food applications. In Enzymes in Food Biotechnology, 1st ed.; Kuddus, M., Ed.; Academic Press: New York, NY, USA, 2019; pp. 369-388.

10. Giosafatto, C.V.L.; Al-Asmar, A.; Mariniello, L. Transglutaminase protein substrates of food interest. In Enzymes in Food Technology: Improvement and Innovation; Kuddus, M., Ed.; Springer Nature Singapore Pte Ltd.: Singapore, 2018; pp. 293-317.

11. Pakseresht, S.; Tehrani, M.M.; Razavi, S.M.A. Optimization of low-fat set-type yoghurt: Effect of altered whey protein to casein ratio, fat content and microbial transglutaminase on rheological and sensorial properties. J. Food Sci. Technol. 2017, 54, 2351-2360. [CrossRef] [PubMed]

12. Giosafatto, C.; Rigby, N.; Wellner, N.; Ridout, M.; Husband, F.; Mackie, A.; Giosafatto, C.V.L. Microbial transglutaminase-mediated modification of ovalbumin. Food Hydrocoll. 2012, 26, 261-267. [CrossRef]

13. Huang, T.; Tu, Z.C.; Wang, H.; Shangguan, X.; Zhang, L.; Zhang, N.H.; Bansal, N. Pectin and enzyme complex modified fish scales gelatin: Rheological behavior, gel properties and nanostructure. Carbohydr. Polym. 2017, 156, 294-302. [CrossRef]

14. Mariniello, L.; Di Pierro, P.; Esposito, C.; Sorrentino, A.; Masi, P.; Porta, R. Preparation and mechanical properties of edible pectin-soy flour films obtained in the absence or presence of transglutaminase. J. Biotechnol. 2003, 102, 191-198. [CrossRef]

15. Xing, G.; Giosafatto, C.V.L.; Rui, X.; Dong, M.; Mariniello, L. Microbial transglutaminase-mediated polymerization in the presence of lactic acid bacteria affects antigenicity of soy protein component present in bio-tofu. J. Funct. Foods 2019, 53, 292-298. [CrossRef]

16. Porta, R.; Di Pierro, P.; Sabbah, M.; Regalado-Gonzales, C.; Mariniello, L.; Kadivar, M.; Arabestani, A. Blend films of pectin and bitter vetch (Vicia ervilia) proteins: Properties and effect of transglutaminase. Innov. Food Sci. Emerg. Technol. 2016, 36, 245-251. [CrossRef]

17. Giosafatto, C.V.L.; Al-Asmar, A.; D'Angelo, A.; Roviello, V.; Esposito, M.; Mariniello, L. Preparation and characterization of bioplastics from grass pea flour cast in the presence of microbial transglutaminase. Coatings 2018, 8, 435. [CrossRef]

18. Lara-Espinoza, C.; Carvajal-Millán, E.; Balandrán-Quintana, R.; López-Franco, Y.; Rascón-Chu, A. Pectin and pectin-based composite materials: Beyond food texture. Molecules 2018, 23, 942. [CrossRef] 
19. Padmaja, N.; Bosco, S.J.D. Preservation of jujube fruits by edible Aloe vera gel coating to maintain quality and safety. Indian J. Sci. Res. Technol. 2014, 3, 79-88.

20. Valdés, A.; Burgos, N.; Jiménez, A.; Garrigós, M. Natural pectin polysaccharides as edible coatings. Coatings 2015, 5, 865-886. [CrossRef]

21. Yossef, M.A. Comparison of different edible coatings materials for improvement of quality and shelf life of perishable fruits. Middle East J. Appl. Sci. 2014, 2, 416-424.

22. Al-Asmar, A.; Naviglio, D.; Giosafatto, C.V.L.; Mariniello, L. Hydrocolloid-based coatings are effective at reducing acrylamide and oil content of French fries. Coatings 2018, 8, 147. [CrossRef]

23. Suyatma, N.E.; Ulfah, K.; Prangdimurti, E.; Ishikawa, Y. Effect of blanching and pectin coating as pre-frying treatments to reduce acrylamide formation in banana chips. Int. Food Res. J. 2015, 22, 936-942.

24. Esposito, M.; Di Pierro, P.; Regalado-Gonzales, C.; Mariniello, L.; Giosafatto, C.V.L.; Porta, R. Polyamines as new cationic plasticizers for pectin-based edible films. Carbohydr. Polym. 2016, 153, 222-228. [CrossRef]

25. Marquez, G.R.; Di Pierro, P.; Esposito, M.; Mariniello, L.; Porta, R. Application of transglutaminase-crosslinked whey protein/pectin films as water barrier coatings in fried and baked foods. Food Bioprocess Technol. 2013, 7, 447-455. [CrossRef]

26. Laemmli, U.K. Cleavage of structural proteins during the assembly of the head of bacteriophage T4. Nat. Cell Boil. 1970, 227, 680-685. [CrossRef]

27. Bourlieu, C.; Ménard, O.; Bouzerzour, K.; Mandalari, G.; Macierzanka, A.; Mackie, A.R.; Dupont, D. Specificity of infant digestive conditions: Some clues for developing relevant in vitro models. Crit. Rev. Food Sci. Nutr. 2014, 54, 1427-1457. [CrossRef]

28. Minekus, M.; Alminger, M.; Alvito, P.; Ballance, S.; Bohn, T.; Bourlieu, C.; Carrière, F.; Boutrou, R.; Corredig, M.; Dupont, D.; et al. A standardised static in vitro digestion method suitable for food-An international consensus. Food Funct. 2014, 5, 1113-1124. [CrossRef]

29. Zeng, X.; Cheng, K.-W.; Du, Y.; Kong, R.; Lo, C.; Chu, I.K.; Chen, F.; Wang, M. Activities of hydrocolloids as inhibitors of acrylamide formation in model systems and fried potato strips. Food Chem. 2010, 121, 424-428. [CrossRef]

30. Wang, H.; Feng, F.; Guo, Y.; Shuang, S.; Choi, M.M. HPLC-UV quantitative analysis of acrylamide in baked and deep-fried Chinese foods. J. Food Compos. Anal. 2013, 31, 7-11. [CrossRef]

31. Krishna, V.N.; Meyyanathan, S.N.; Karthik, Y.; Hemnath, E.; Satiesh, K.R.; Usha, K. A simple and validated RP HPLC method for the estimation of acrylamide in potato chips. World J. Pharm. Pharm. Sci. 2014, 3, 1468-1476.

32. Michalak, J.; Gujska, E.; Kuncewicz, A. RP-HPLC-DAD studies on acrylamide in cereal-based baby foods. J. Food Compos. Anal. 2013, 32, 68-73. [CrossRef]

33. AOAC Official Method 960.39 Fat (Crude) or Ether Extract in Meat First Action 1960 Final Action; AOAC International: Arlington, MA, USA, 2006.

34. AOAC Official Method 950.46 (39.1.02) Moisture (M); AOAC International: Arlington, MA, USA, 2006.

35. Bourne, M.C. Texture profile analysis. Food Technol. 1978, 32, 62-66.

36. Meullenet, J.F.; Lyon, B.G.; Carpenter, J.A.; Lyon, C.E. Relationship between sensory and instrumental texture profile attributes. J. Sens. Stud. 1998, 13, 77-93. [CrossRef]

37. Salazar, R.; Arámbula-Villa, G.; Hidalgo, F.J.; Zamora, R. Mitigating effect of piquin pepper (Capsicum annuum L. var. Aviculare) oleoresin on acrylamide formation in potato and tortilla chips. LWT-Food Sci. Technol. 2012, 48, 261-267. [CrossRef]

38. Salazar, R.; Arámbula-Villa, G.; Vázquez-Landaverde, P.A.; Hidalgo, F.J.; Zamora, R. Mitigating effect of amaranth (Amarantus hypochondriacus) protein on acrylamide formation in foods. Food Chem. 2012, 135, 2293-2298. [CrossRef]

39. Sayon-Orea, C.; Bes-Rastrollo, M.; Basterra-Gortari, F.; Beunza, J.; Guallar-Castillon, P.; De La Fuente-Arrillaga, C.; Martinez-Gonzalez, M.A. Consumption of fried foods and weight gain in a Mediterranean cohort: The SUN project. Nutr. Metab. Cardiovasc. Dis. 2013, 23, 144-150. [CrossRef]

40. Garmakhany, A.D.; Mirzaei, H.O.; Maghsudlo, Y.; Kashaninejad, M.; Jafari, S.M. Production of low fat French-fries with single and multilayer hydrocolloid coatings. J. Food Sci. Technol. 2014, 51, 1334-1341. [CrossRef]

41. Mahajan, I.; Sonka, C.; Surendar, J. Study on the effective reduction of oil up-take by the application of edible hydrocolloid coatings on French fries. Int. J. Res. Eng. Adv. Technol. 2014, 2. 
42. Pinthus, E.J.; Weinberg, P.; Saguy, I.S. Criterion for oil uptake during deep-fat frying. J. Food Sci. 1993, 58, 204-205. [CrossRef]

43. Mansour, E.H. Quality of deep-fat frying Falafel balls as influenced by various fibers and hydrocolloids. Minufiya J. Agric. Res. 2003, 28, 491-502.

44. FA1005-Improving Health Properties of Food by Sharing Our Knowledge on the Digestive Process (INFOGEST). Available online: https://www.cost.eu/actions/FA1005/\#tabs \T1\textbar\{\}Name:overview (accessed on 20 May 2019).

45. Opazo-Navarrete, M.; Altenburg, M.D.; Boom, R.M.; Janssen, A.E.M. The effect of gel microstructure on simulated gastric digestion of protein gels. Food Biophys. 2018, 13, 124-138. [CrossRef]

(C) 2019 by the authors. Licensee MDPI, Basel, Switzerland. This article is an open access article distributed under the terms and conditions of the Creative Commons Attribution (CC BY) license (http://creativecommons.org/licenses/by/4.0/). 